\title{
Electronic Commerce: Validity of the Digital Contract Based on Indonesia Legislation Perspective
}

\author{
Sunaryo $^{1}$ \\ Faculty of Law Lampung University, \\ Bandar Lampung, Indonesia
}

\author{
Hanifah Nuraini ${ }^{2}$ \\ Post Graduated Faculty of Law Lampung University \\ , Bandar Lampung, Indonesia
}

\begin{abstract}
Technological developments in the economic sector, a transaction renewal known as electronic commerce. Transactions that occur in e-commerce are categorized as digital contracts. The use of digital contracts in Indonesia does not escape a number of problems, which is legal. Legal issues that appear in this digital transaction are related to the element of validity. Digital contracts as a new type of contract cannot be equated with conventional contracts, because there are different limitations. This condition resulted in the implementation of digital contracts being facilitated thoroughly by regulations. This paper will examine legal issues in the implementation of digital contracts and understand the legality of digital contracts based on legal instruments in Indonesia.
\end{abstract}

Keywords:- Digital Contract, Validity, and Electronic Commerce.

\section{INTRODUCTION}

The era of globalization marked by the revolution of industry 4.0 [1] converts every side of life to digital modern. The evolution of technology accompanied by a digital system have more or less affected the way people live together with internet. The evolution of internet can acceleration human activities more optimally. Therefore, digital mode adaptation continues to be carried through various sectors that affect human activities. The evolution of information technology also occurs in the economic sector, one of them is marked by the presence of the concept of digital transactions.

Indonesia's involvement in the world economic forums has also a little bit influenced economic policy in Indonesia, one of which is the policy about the payment system. In Indonesia, the payment system in general still uses cash as means of payment, but actually with the large amount of money circulating in society can trigger an increase inflation. Because of this some other countries such as Japan, Singapore, Britain and the United States already implemented digital transaction [2].
The evolution of digital transactions in Indonesia is initiated by the management and use of digital payment instrument products which are quite massive and intensive. The existence of this digital transaction is based on the necessary for more complex transactions, reaching more customers and merchants, creating high efficiency, ease and practice. For instance, new types of purchasing relationships such as auction between individuals online-have in the need for peer-to-peer payment methods that allows individuals to e-mail payments to the other party [3].

However, on the other side, digital transactions contain many problems, especially on the implications of legal issues [4]. Those problems come from the practice of contract implementation, including its validity from a law perspective. Legal issues that appear in digital transactions are related to contract law. The conventional contract terms in Indonesian positive law have not been fully able to reach digital system agreement.

Digital transactions include legal relationships between parties. This connection is formed from a legal contract that binds every legal subject in arrange digital transactions. The compatibility of legal contract in a digital agreement cannot be equated with a conventional contract. Because legal contracts contain elements based on modern technology. The adoption of information technology and internet networks within the framework of a legal agreement creates a new contract. A renewal contract is a condition when the terms of the conventional contract are combined with elements of validity in digital technology [5]. Every business activity can be ascertained from an agreement through a contract. Therefore, the renewal of transaction patterns requires adjustments within the framework of the national contract law system.

In Indonesia, there is no law-level rule that specifically regulates contracts in digital transactions. The enforcement of legal rules about the validity ratio of digital transactions refers to the provisions in Indonesian Civil Law and other electronic transaction provisions. However, these two legal components have not been able to fully cover the aspects of the agreement in a digital legal contract. This research will discuss about the implementation of digital transactions in terms of the structure and legal principles. Comprehensively examine about the conceptual digital-based agreement and analyze the validity of legal contracts Indonesian law perspective. 


\section{RESULT AND DISCUSSION}

\section{A. The concept of e-commerce digital contract}

An agreement is a legal relation that happens because of the law, in the form of an act, event or situation. Legal relation has created a rights and duties as a legal consequence. The rights and duties in referred to will be relate to the fulfilment of the agreement contract. The object of the agreement is something that is useful, valuable and precious to the legal subject. Meanwhile, legal subject are all the things that can support their rights and duties or have legal authority (rechtsbevoegdheid).

Definition of e-commerce, according to language (etymology) is as follows: (E) electronic is electronic science (electric charge), electronic devices, or all things related to the world of electronics and technology. Meanwhile, (C) commerce is trade, commerce [6]. Association for Electronic Commerce simply defines e-commerce as an electrical business mechanism. CommerceNet, an industry consortium provides a complete definition of the use of computer networks as a means of creating business relationships. Not satisfied with this definition CommerceNet append that in ecommerce there is a process of buying and selling of services or products between two parties via the internet or exchange and distribution of information between two parties in one company using the internet [7].

In legislation, article 1 point 2 of The Act Number 19 year of 2016 concerning Electronic Information and Transactions (hereinafter written as EIT Act) defines electronic transactions as legal act that are carried out by combining computer-based electronic system networks with communication systems, which are further facilitated by the existence of a global computer network or the internet.

From exposure above, it can be concluded that ecommerce agreement has the following characteristic:

- The occurrence of a legal act in the form of transaction between two or more parties

- There is an exchange of goods, services or information;

- The internet is the main medium in the trading process or mechanism

The concept of an agreement in e-commerce basically concern legal relations according to civil characteristic. It means that the agreement contains the interests of the parties in the property law. The scope of property law that can be interpreted from the object of e-commerce is the exchange of goods, services or information in digital form. E-commerce legal relations appear as manifestation of freedom of contract freedom of contract principle. This principle is also known as laissez faire. Aduru Rajendra said the freedom of contract doctrine is an extension of 'one of the most cherished aspects of individual liberty [8]. It is nothing but leaving the parties as the best judges of their own bargains and persuading them to subjects to their own obligations. Each agreement that is born from the contract implies that the agreement appears from the will of parties. This is enhanced by Article 1338 of the Indonesian Civil Law which states that all agreements made legally, apply as law for those who make them.
B. The validity of e-commerce according to Indonesian legislation

E-commerce has implications for various sectors, one of which has an impact on the legal sector. There are no rules that specifically regulate the issue of e-commerce. Regulation regarding e-commerce still use Indonesian Civil Law Book III, especially arrangements regarding contract issues that occur in e-commerce. The contract in e-commerce occurs between two parties in which one party promises the other to do something. This is in accordance with Article 1313 of the Indonesian Civil Law, which states that a contract is an act whereby one or more people bind themselves to one or more people.

Although it has different characteristics from conventional agreements, the essence of implementing digital contracts with conventional contracts is the same, namely to bind oneself to one other. Therefore, what is the condition for the validity of a contract contained in the Indonesian Civil Law can also be used as and qualification for the validity of a digital contract. However, based on lex specialis derogat legi generali principle, the regulation of digital contract in Article 47 paragraph (2) of Government Regulation Number 82 Year of 2012 concerning Electronic System and Transactions (hereinafter written as EST GR) must be prioritized [9]. The digital contract validity requirements according to EST GR include:

- The agreement of the parties

- Capacity each party

- Certainty of terms

- Consideration

The terms of the validity of a digital contract basically have no difference with the legal requirements of a conventional contract as regulated in Article 1320 of Indonesian Civil Law. It's just that a slightly different implementation is possible due to the involvement of digital technology. The implementation of these differences can be illustrated by the process the contract is formed. For example, the parties' conventional contracts are usually carried out on paper based, whereas in digital contracts, the legal relations of the parties are formed from paperless contracts. The paperless nature means that digital contracts are only in the form of digital data and are intangible objects. Even though digital contracts are a form of legal document that must legally have the interests of the parties. The question is whether the legality of legal documents must be real and tangible? Then what about activities that are carried out digitally?

It is important to understand that the legality element of a contract can be realized by fulfilling the indicators of the validity of the contract. Therefore, the parties must understand and fulfill the legal requirements of the digital contract, because the legality of a digital contract will have an impact on the legal consequences and consequences of contract implementation. In addition, the legality of the digital contract also serves as a guarantee of legal certainty for the parties. 
Is used to format your paper and style the text. All margins, column widths, line spaces, and text fonts are prescribed; please do not alter them. You may note peculiarities. For example, the head margin in this template measures proportionately more than is customary. This measurement and others are deliberate, using specifications that anticipate your paper as one part of the entire proceedings, and not as an independent document. Please do not revise any of the current designations.

\section{The agreement of the parties}

Agreement means there is a free will between the parties regarding the main things desired in the contract. In this case, the parties must have a free will (voluntary) to bind themselves, in which the deal can be stated explicitly or tacitly [10]. The terms of agreement are also known in the principle of contract law as consesualism principle. This principle can be realized when the transaction process reaches an agreement.

There are two main things that customers usually do in cyberspace. The first is to see the products or services advertised by related companies through their web site (online ads). Second, looking for certain data or information needed in connection with the e-commerce process to be carried out using a shopping cart. If you are interested in the products or services offered, customers can carry out trade transactions with standard orders, by filling in the order form [4]. For example, customers who want to buy products in merchant digital services will be faced with the process of selecting the desired product. Then the customer must click on the product he wants to continue at the order confirmation and payment stage. The order confirmation stage is the stage for filling the order form based on standard orders set by providers. This process is characterized as a form of agreement between customers and merchants on the sale and purchase digital contract.

Furthermore, to find out when an agreement point occurs between buyers and sellers in e-commerce digital transactions, it is necessary to analyze several theories through theories such as [7]:

\section{a. Offer and acceptance theory}

In principle, this theory justifies that a will agreement occurs after an offer from one party is followed and is followed by acceptance by the other party in the contract. This theory has a weakness when applied to ecommerce, because there will be a situation where the online ordering process suddenly stops. This is due to the power to complete the product ordering process under consumer control. Thus, if the consumer suddenly stops the order process, the deal is immediately canceled.

\section{b. Wills theory}

This theory distinguishes between what is stated and what is desired of the party making the promise. Concerning what is desired and declaring what is stated does not apply. This theory is not appropriate to apply to e-commerce, because it cannot be determined when the agreement occurs, because it does not provide legal certainty for the parties.

\section{c. Statement theory}

This theory is the opposite of wills theory, which emphasizes what is stated rather than what is desired. So according to this theory, the customer is declared to have agreed when he has stated his will by filling in the applicable order form. Likewise, what the merchant stated regarding the transaction approval process applies. Although it is possible for customers to provide incorrect data and merchants approve it.

\section{d. Confirmation theory}

According to this theory, an agreement is considered to occur when the party making the offer receives a reply to the confirmation of the answer from the party receiving the offer. In e-commerce the agreement is stated to occur when the merchant has received an answer from the customer for the confirmation news of the answer he has submitted. This includes information provided by customers who meet the requirements or are declared valid.

The correct theory to be applied in a digital ecommerce contract is confirmation theory. This is based on the actions of the party statement wills. Article 20 of the EIT Act states that an electronic transaction occurs when the transaction offer sent by the sender is received and approved by the recipient. However, such consent must be made by means of an electronic acceptance statement (for example by sending a confirmation email).

\section{Capacity each party}

Basically, a person or legal entity that is mature, common sense and not prohibited by law (such as not being declared bankrupt by the court) is a capable or legally authorized legal subject. Two types of legal subjects have certain qualifications, namely:

\section{a. Individual person}

Adult indicators according to Article 330 of the Indonesian Civil Law, are 21 years of age or already / have been married. Meanwhile, the common sense element is a person who does not experience mental disorders and should be consciously able to enter into an agreement.

\section{b. Legal entity}

Every legal entity that has the legality of implementation can carry out the agreement as long as it is not being or has been prohibited by law. According to the provisions of Article 1653 of the Civil Code, there are 3 (three) forms of legal entities seen from the aspect of their position, namely legal entities established by the government (BUMN, government agencies), legal entities recognized by the government (PT, cooperatives et cetera) and legal entities with the aim of certain (foundations, NGOs et cetera).

The element of proficiency in e-commerce is difficult to measure, because everyone (without being limited by a certain age) can carry out digital transactions. One of the weaknesses of e-commerce is the difficulty in identifying parties who carry out digital transactions. Budhiyanto identified the parties involved in e-commerce transactions consisting of [11]: 
a. Seller (merchants), namely companies that offer their products via the internet or in Article 1 point 18 of the EIT Act are referred to as senders. "Sender is a legal subject who sends electronic information and/or electronic documents". To become a seller / merchant / sender, one must register himself as a merchant account at a bank, this is so that merchants can receive payments from customers in the form of credit cards.

b. Consumers are people who want to obtain goods and/or services through digital purchases or in Article 1 point 19 of EIT Act as recipients. Recipient is a legal subject who receives electronic information / electronic documents from the sender. Consumers who will shop via the internet can have the status of individuals or companies. If the consumer is an individual, then what needs to be considered is how the payment system is used, whether using a credit card or cash / manual payments possible. This is because not all consumers who shop on the internet are credit card holders. A credit card holder is someone whose name is printed on a credit card issued by the issuer based on the agreement that has been made.

c. Acquirer and Issuer, each of which is a legal entity and functions as an intermediary. Acquirer is a collection intermediary and payment intermediary. Meanwhile, Issuer is a digital payment instrument issuing company.

d. Certification authorities are the third party that hold the right to issue certificates to merchants / sellers, to issuers and in some cases to consumers. Certification authorities are entities, either individuals or legal entities, that are entrusted with examining and evaluating the feasibility of administering e-commerce transactions.

\section{Certainty of terms}

A certainty relates to the object of a contract, which means that the object of the contract must be clear, can be determined and calculated the type and quantity, permitted by law and possible for the parties. Transactions in e-commerce are basically not much different from conventional transactions which rely $\mathrm{n}$ a tangible form that can be touched, physical distribution and there is a place for transactions. In e-commerce this also occurs but the product to be traded does not appear physically but in the form of information about the product, besides that in e-commerce there is a distribution of language or instruction codes which will eventually bring up information on the product that will be the offer and how to make a transaction.

Article 1333 of the Indonesian Civil Law states that a contract must have as a principal and item of which the type at least is determined. It means that contract must have goods and their quantity and type as the object of contract [12]. Digital contract objects consist by three types, such as goods, services and information [13]. The provision of contract object is the duty and responsibility of the merchant as the seller, provider as the e-commerce operation and it is also possible for other digital transaction instruments which essentially have the capacity to provide transaction products.

\section{Consideration}

Consideration means that the contract must be made based on good faith. Article 1335, 1336 and 1337 of the Indonesian Civil Law states that consideration is declared prohibited if it is contrary to law, decency and public order. Causa is defined as what the parties to the contract want to reached. The consideration in Article 1320 of the Indonesian Civil Law are related to the contract clause as an objective to be reached by the parties. The act does not care about what causes the parties to enter into the contract, but what is monitored by Act is the contract clauses.

In digital contract, the formula of contract clause should contain the fulfilment of the rights and duties of the parties to the object of contract. For example, contract between buyer and seller, the goal to be reached is a service for a product or service that is delivered to the buyer and in return a money is given to the seller.

Consideration conditions are intended to limit the implementation of the freedom of contract principle in transaction. Because the implementation of contract that violate the provisions of Act, morality and public order can harm the parties and the state economy. E-commerce operators can experience various risks of loss of they do not maintain and regulate the types of transactions on objects that are lawful and accountable. Therefore, it is important for digital contract players to meet and implement this requirement.

Based on the description above, it can be understood that the validity of digital contracts in the implementation of e-commerce must be implemented based on the terms of the validity of the digital contracts. The validity of digital contracts with reference to these four conditions is still unable to accommodate the interests of legal guarantees in the dispute resolution process. This is because digital contracts are in the form of paperless documents. Even though it is classified as legally valid, the power of proof of e-commerce transactions is very weak.

Several previous studies have emphasized the application of digital signatures to provide legal strength of evidence for e-commerce transactions [14]. However, this reduces the essence of e-commerce practicality. The United Nations Commission on International Trade Law (UNCITRAL) Model Law on Electronic Commerce which is a reference for the making of Laws and Laws on e-commerce throughout the world community, states in Article 5 UNCITRAL Model Law on Electronic Commerce that Information shall not be denied legal effect, validity or enforceability solely on the grounds that it is in the form of a data message [15]. The data message is meant if its authenticity has been proven using techniques and instruments as appropriate. So that contracts in e-commerce are made by the parties, with these rules providing legal guarantees for the contracts made. 


\section{CONCLUSION}

Before One of the evidences of advances in information technology that consumers feel the benefits of in the trade sector is electronic commerce (e-commerce). Through ecommerce, consumers have wider space for transactions, so that consumers have the ability to collect and compare the goods and / or services they want and consumers become more active. In reality, this condition has not yet been followed by legal developments that can keep pace with the accelerated advancement of information and communication technology.

So far, in Indonesia there are two laws regulating ecommerce activities, namely The Act Number 19 year of 2016 concerning Electronic Information and Transactions and The Act Number 7 year of 2014 concerning Trade and one Government Regulation, namely Government Regulation Number 82 Year of 2012 concerning Electronic System and Transactions which are the implementing rules of EIT Act, in addition to positive laws that are already related to civilization, namely Indonesian Civil Law.

Therefore, efforts to harmonize regulations are needed so that e-commerce activities have legal certainty and provide guaranteed protection for every actor of e-commerce activity. In fact, considering the unique characteristics of ecommerce activities, the author also proposes that ecommerce be made in its own rules, in other words Sui Generis.

\section{REFERENCES}

[1]. S. Palinggi and L. R. Allolinggi, "Analisa Deskriptif Industri Fintech di Indonesia: Regulasi dan Keamanan Jaringan dalam Perspektif Teknologi Digital," Ekon. dan Bisnis, vol. 6, no. 2, p. 177, 2020, doi: 10.35590/jeb.v6i2.1327.

[2]. R. Tazkiyyaturrohmah, "TRANSAKSI KEUANGAN MODERN," Muslim Herit., vol. 3, no. November 2017, pp. 21-39, 2018.

[3]. S. Sumanjeet, "Emergence of payment systems in the age of electronic commerce: The state of art," in $1 s t$ South Central Asian Himalayas Regional IEEE/IFIP International Conference on Internet, AH-ICI 2009, 2009, vol. 3, no. 3, pp. 18-40, doi: 10.1109/AHICI.2009.5340318.

[4]. C. M. Indah, "ASPEK PERJANJIAN ELECTRONIC COMMERCE DAN IMPLIKASINYA PADA HUKUM PEMBUKTIAN DI INDONESIA," $M M H$, vol. 39, no. 2, pp. 172-184, 2010.

[5]. M. Shnikat, A. Alzubi, and M. Aljaber, "THE LEGAL FRAMEWORK OF ELECTRONIC CONTRACT IN THE JORDANIAN," Glob. J. Polit. Law Res., vol. 5, no. 5, pp. 46-62, 2017.

[6]. S. Santoso, "Sistem Transaksi E-Commerce Dalam Perspektif Kuh Perdata Dan Hukum Islam," Ahkam J. Huk. Islam, vol. 4, no. 2, pp. 217-246, 2016, doi: 10.21274/ahkam.2016.4.2.217-246.
[7]. B. H. Mantri, "PERLINDUNGAN HUKUM TERHADAP KONSUMEN DALAM TRANSAKSI E-COMMERCE," 2007.

[8]. M. Mandey, "Implementasi Hukum Perlindungan Konsumen Dalam Perjanjian Standar," Lex Soc., vol. III, no. 10, pp. 156-162, 2015.

[9]. W. S. Putri and N. Budiana, "Keabsahan Kontrak Elektronik Dalam Transaksi E-Commerce Ditinjau dari Hukum Perikatan," J. Anal. Huk., vol. 1, no. 2, pp. 300-309, 2018.

[10]. G. Biondi, "Analisis Yuridis Keabsahan Kesepakatan Melalui Surat Elektronik (e-mail) Berdasarkan Hukum Indonesia," Premise Law J., vol. 19, pp. 1-20, 2016.

[11]. R. Roihanah, "PERLINDUNGAN HAK KONSUMEN DALAM TRANSAKSI ELEKTRONIK ( E COMMERCE )," Justicia Islam., vol. 8, no. 2, pp. 97122, 2011, doi: 10.21154/justicia.v8i2.535.

[12]. W. H. Suseno, "KONTRAK PERDAGANGAN MELALUI INTERNET(ELECTRONIC COMMERCE) DITINJAU DARI HUKUM PERJANJIAN," 2008.

[13]. R. USMAN, "Karakteristik Uang Elektronik Dalam Sistem Pembayaran," Yuridika, vol. 32, no. 1, p. 134, 2017, doi: 10.20473/ydk.v32i1.4431.

[14]. E. Hariyanto, "E-COMMERCE DI INDONESIA Abstract:," Al-ahkam, vol. IV, no. 2, pp. 293-310, 2009.

[15]. T. Rahmatullah, "Analisis Permasalahan Hukum ECommerce dan Pengaturannya di Indonesia," J. Huk. Media Justicia Nusant., vol. 7, no. 2, pp. 10-23, 2017, doi: 10.13140/RG.2.2.27189.52967. 